\title{
Impact of Dividend Policy on Share Price of Commercial Bank in Nepal Raj Kumar Baral ${ }^{*}$ and Ajay Pradhan ${ }^{\star *}$
}

\begin{abstract}
The purpose of this study is to examine the impact of dividend policy on the share price of commercial bank in Nepal. The study is based on pooled cross sectional data of 10 commercial banks. Banks were selected on the basis of their performance on stock market of Nepal, i.e. top gainers and top losers and data are collected from Nepalese commercial banks listed in NEPSE from the F/Y 2012/13 to F/Y 2016/17. The paper investigates the relationship between dividend announcement, EPS, P/E ratio, DPR, on stock price by using Descriptive Statistics, Correlation and Regression, ANOVA and Wilcoxon Signed Rank Test. The articles conclude that except DPR, the other factors like EPS, P/E ratio have positive relationship with stock price among them $P / E$ is the strongest factor that affects the share price in case of top gainer commercial banks whereas EPS, P/E ratio and DPR have positive influence on stock price among them DPR is the strongest factor that affects the share price in case of top loser bank.
\end{abstract}

Key Words: Reaction of Share Price, Wilcoxon Matched Paired Test, Earning Per Share, Price/Earning Ratio, Dividend Payout Ratio, Market Price Per Share

${ }^{\star}$ Visiting Faculty, Nepal College of Management, Kathmandu University, Nepal Email: baralraju@gmail.com. ${ }^{*}$ Frelance researcher, pradhan.ajaya1995@gmail.com 


\section{Introduction}

In general, dividend payment is not an expense to the firm but the sharing or distribution of profits to each of the firm's shareholders according to the ratio of their shareholding in the firm. Usually, a firm announces dividend on the corporate profits, decided by the board of directors of the firm during Annual General Meeting (AGM). The dividend can be distributed either in cash or by capitalization of profits as stock dividend. Miller and Modigliani (1961) have asserted that given firms' optimal investment policy, the firm's choice of dividend policy has no impact on shareholders wealth. However, Gordon (1963) argues that dividend policy does affect the value of firm and market price of shares. $\mathrm{He}$ asserts that shareholders prefer the early resolve on uncertainty, and willing to pay a higher price for a share which has a greater dividend payout ratio. He agrees that investors always prefer current income in the form of dividends over capital gains.

In the context of Nepal, only few companies are paying dividend but many other companies are not paying stable dividend. There are some companies which have never paid dividend to their investors. Dividend on share is an important indicator that shows the performance of banks and thereby attracting the investors. Investors examine the dividend policy of the banks before they decide to invest on stock market but due to fluctuation on dividend policy of commercial banks of Nepal, investors are unable to forecast the future cash flow from cash dividend (Bhandari and Pokharel, 2012). It has been perceived that company which has grown their dividend generally experience an increase in its stock price and those companies which don't pay or lowers its dividend, leads to a fall in stock price trend. Hence, It shows dividend affects the stock price of the company but several researchers argue that it is the information on payment of dividend that affects the stock price. In fact, that dividend works as a simple sufficient signal of management's interpretation of the firm's current performance and its future prospects.

As the relationship between dividend policy and the movement of stock prices is debatable, this paper aims at answering the question- What is the impact of dividend policy or dividend announcement, dividend payout ratio, earning per share, price-earnings ratio on the value of commercial banks listed in the NEPSE? The main objective of this study is to determine the impact of dividend policy on market price per share with special reference to commercial banks listed in NEPSE.

The remaining part of the research reviews the related literature followed by research methodology in section III. Fourth section analyses and interprets data and the final sections conclude the research with some recommends.

\section{Hypothesis of the study}

This study has offered the number of affecting variables into the null hypothesis (Ho) to 
Raj Kumar Baral and Ajay Pradhan: Impact of Dividend Policy on Share Price of Commercial Bank in Nepal

confirm the statistical significance of the association between different selected variables: H1: There is statistically significant relationship between dividend announcement and movement of share price.

$\mathrm{H} 2$ : There is statistically significant relationship between dividend payout ratio and movement of share price.

H3: There is statistically significant relationship between earning per share and movement of share price.

H4: There is statistically significant relationship between price-earnings ratio and movement of share price.

\section{Review of Literature}

According to Hussainey, Mgbame, \& Chijoke-Mgbame (2011), The study on "Dividend Policy and Share Price Volatility" shows the positive relations between dividend yield and stock price changes and negative relations between dividend payout ratio and market price per share. Their results further show that the firm's earnings, growth rate, level of debt and size also causes the change in stock price of the UK.

Adres, Betzer, Bongard, Haesner and Theissen (2009) conducted a study in Germany to investigate dividend announcement, market expectations and corporate governance. The results of the study depicted that there is a significant relationship between the market expectations and dividend announcement whereby if the dividend followed to prior market expectation then the share prices increased after dividend announcement.

For Faloye and Oluwole (2014) dividend announcement is always expected to deliver some information to investors in relation to their corporations' performance since the stock is always considered as being bullish or bearish. Securities market is supposed to be bullish if the stock prices are consistently on an upward trend and bearish if there are consistently downward. There is a significant positive relationship between dividend announcement and share price on a bullish market whereas bearish market listed as a negative significant relationship.

In the context of Nepal, limited research works have been conducted in dividend payout. Adhikari (2063) has found that there were variances in the dividend payment by the commercial banks of Nepal. There was no stability in the dividend payout ratio of the commercial banks. Thus, he has recommended the investors to consider the high profit of companies for purchasing shares.

Bhattarai (2052) has concluded that there is a positive relationship between cash flow and current profit and dividend percentage of share. There are no criteria to adopt dividend payout ratio and it is observed that there is a negative relationship between payout ratio 
and valuation of shares. Similarly, he found that there was a negative relationship between MPS and stockholders' required rate of return also.

Bista (2062) in his study on the "Dividend Policy and Practices of Listed Joint Venture Commercial Banks and Manufacturing Companies" found that there was a positive correlation between DPS and MPS of commercial banks whereas no correlation was found in manufacturing companies.

\section{Factors Influencing Dividend Payment}

Various researchers have established several factors that influence dividend payments by firms. The following are four of the most common factors:

\section{Amount of Earnings}

For the company to be able to pay dividends there must be sufficient earnings after tax available for distribution to the shareholders. Companies are largely required to pay dividend out of the profits made in a particular year and not from retained earnings. Lintner (1956) in his classical study found that a firm's net earnings are the critical determinant of dividend change.

\section{Cash Flows}

In deciding on dividend payment, the company has to consider its cash flow situation. This is to ensure if liquid its enough is to cover the cash outflow in dividend payment and its operations thereafter. Alli et al. (1993) argue that dividend payments depend more on cash flows, which reflect the company's ability to pay dividends.

\section{Previous dividend}

The manager of firms are not to reduce the previous level of dividend payment because of the signal such action would express to the investors in line with the dividend signaling hypothesis. In his classic study on dividend policy, Lintner (1956) interviewed a sample of corporate managers and found that managers demonstrate a "reluctance (common to all companies) to reduce regular rates once established and a consequent conservatism in raising regular rates".

\section{Leverage}

Firms that finance their activities mostly with debt rather than equity put pressure on their liquidity. Debt principal and interest payments reduce the ability of firms to have residual income to guarantee dividend payment. Consequently, it is expected that, there is always negative relationship between debt and amount of dividend paid for a period. Kowaleski et al (2007) argue that more obligated firms favor to pay lower dividends. 


\section{Factors Influencing Share Price}

The factors influencing share prices may be categorized as either micro or macro environment factors:

\section{Micro-economic environment factors}

These are factors that are within the firm and the industry in which it operates. They may include the firm's dividend policy, performance in terms of profitability, management quality and earnings ratios among others. High dividend policy may attract high priced stocks while low dividend policy may attract low priced stocks.

\section{Macro-economic environment factors}

These are factors affecting the whole economy within which the firm operates. These factors include interest rates, inflation rate, and fiscal measures taken by the government in managing the economy and foreign exchange rates among others. In developing countries like Nepal, political factor is one of the important determinants of share price of commercial banks rather than wisely understanding of fundamental and technical analysis by the investors.

\section{Research Methodology}

The study is based on secondary data analysis. In order to achieve the objective of this study there are 27 commercial banks listed in NEPSE which are considered as population of the study and 10 commercial banks are selected as sample of the study. Judgmental or purposive sampling technique has been used in case of availability of five years data from selected banks. Banks are selected on the basis of their performance on stock market of Nepal, i.e. top gainers and top losers. The required data are collected from annual report, official website of respective banks, ShareSansar and NEPSE data. The research design employed in this study is descriptive and causal relationship as it deals with impact of dividend policy on share price of commercial bank in Nepal. Moreover, the study examines the effect of dividend announcement, earning per share, dividend payout ratio and price-earning ratio. The data are gathered from the F/Y 2012/13 to 2016/17. For the purpose of analyzing the impact of dividend announcement, the daily closing price data of the selected banks' stock price for the period from 5 days before and after the dividend declaration date i.e., ( -5 days to +5 days) are taken and the Wilcoxon Matched Pairs Test has been used for analytical purpose. The following table shows the sample description of the study: 


\begin{tabular}{lllll}
\hline S.N. & Symbol & Top Gainer & Symbol & Top Loser \\
\hline 1. & NABIL & Nabil Bank Ltd. & KBL & Kumari Bank Ltd. \\
2. & NIBL & Nepal Investment & CCBL & Century Commercial Bank \\
& & Bank Ltd. & & Ltd. \\
3. & SCB & Standard Chartered & JBNL & Janta Bank Nepal Ltd. \\
& & Bank Ltd. & & \\
4. & EBL & Everest Bank Ltd. & MEGA & Mega Bank Ltd. \\
5. & ADBL & Agricultural & CBL & Civil Bank Ltd. \\
& & Development Bank & & \\
& & & \\
\hline
\end{tabular}

\section{Data Analysis and Discussion}

\section{Statistics Analysis}

This section deals with the impact of dividend announcement, EPS, P/E ratio and DPR on the market share price of 'Top Gainers' and 'Top Loosers' of Class 'A' bank in Nepal.

\section{Table 4.1: Descriptive Statistics of EPS, P/E ratio, DPR and MPS}

\begin{tabular}{cccccc}
\hline \multicolumn{5}{c}{ Descriptive Statistics } \\
\hline & $\mathrm{N}$ & Minimum & Maximum & Mean & Std. Deviation \\
\hline EPS & 50 & -8.9400 & 91.8800 & 35.019880 & 26.8108023 \\
PE & 50 & -27.1812 & 81.3559 & 26.340667 & 20.6170501 \\
DPR & 50 & .0000 & 2.9659 & 0.745633 & 0.5864718 \\
MPS & 50 & 84 & 3385 & 943.54 & 928.153 \\
\hline
\end{tabular}

Table 4.1 shows the descriptive statistics of 10 sampled commercial banks listed on NEPSE from $2012 / 13$ to $2016 / 17$. Descriptive statistics shows that the mean of the EPS is 35.01988 with standard deviation of 26.8108 and ranges from -8.94 to 91.88 . This implies that value of EPS can vary on both sides by 26.8108 and the mean of the $\mathrm{P} / \mathrm{E}$ is 26.3407 with standard deviation of 20.617 and ranges from -27.181 to 81.356 which means the value of P/E can deviate on both sides by 20.617. Similarly, DPR has mean value of 0.7456 and standard deviation of 0.58647 ranging from 0 to 2.9659 which means the value can be deviated by 0.586471 . Finally, market stock price (MPS) has mean value, standard deviation and minimum and maximum range of $943.54,928.153,84$ to 3385 respectively shows that minimum and maximum value can be deviated by 928.153 . 


\section{Reaction of Dividend Announcement on Share Price}

The technique of analysis with reference to Appendix I, shows the value of NABIL is 2.02156 which is more than the table value of 1.645 at $5 \%$ level of significance, which rejects the null hypothesis stating that there is significant impact of dividend announcement in the market price of share. This means the market price of NABIL's share respond to the declaration of dividend. Similar situation can be traced in the case of SCB, EBL, ADBL which are top gainer commercial banks and CCBL, JBNL, MEGA, CBL which are top loser whereas the $\mathrm{Z}$ value of NIB i.e. top gainer bank is 0.943396 and KBL i.e. top looser bank is 0.673854 which is less than 1.645 , suggesting that we fail to reject null hypothesis. Analysis of EPS, P/E ratio, DPR and MPS

Table 4.2: Correlation analysis of factor affecting share price of top gainer commercial banks in Nepal

\section{Correlations}

\begin{tabular}{ccccc}
\hline & EPS & PE & DPR & MP \\
\hline EPS & 1 & & & \\
PE & -0.167 & 1 & & \\
DPR & $-0.537^{* *}$ & $0.565^{* *}$ & 1 & 1 \\
MPS & $0.406^{*}$ & $0.797^{* *}$ & 0.128 & \\
\hline
\end{tabular}

**. Correlation is significant at the 0.01 level (2-tailed).

*. Correlation is significant at the 0.05 level (2-tailed).

Table 4.2 explains the correlation between factors affecting market share price of top gainer commercial banks in Nepal. The major focus is given to EPS, P/E, DPR, MPS. Here, we can observe P/E and MPS have highest influence in each other with 0.797 correlation score. Similarly, EPS and MPS have 0.406 correlation score resulting a significant influence over each other. Weak positive correlation can be traced between DPR and MPS with correlation value of 0.128 . P/E and DPR have moderate positive correlation with value of 0.565 whereas EPS and P/E have weak negative relationship and EPS and DPR have moderately negative relationship with each other with value of -0.167 and -0.537 respectively. 
Table 4.3: Regression Model Summary for top gainer commercial banks in Nepal

Model Summary

\begin{tabular}{cccc}
\hline $\mathrm{R}$ & R Square & Adjusted R Square & Std. Error of the Estimate \\
0.973 & 0.947 & 0.939 & 224.267 \\
\hline
\end{tabular}

Table 4.3 above shows the model summary for the regression analysis between the market share price and EPS, P/E, DPR in top gainer commercial banks. The R squared was 0.947 which shows the model explanatory power depicted that $94.7 \%$ of the changes in the share price in top gainer commercial banks be explained by the announcement of dividend while the remaining percentage can be explained by other factors excluded in the model. The adjusted $\mathrm{R}$ square was $93.9 \%$ which shows the model explanatory power with the exclusion of the constant variable in the regression model. In addition, the coefficient for $\mathrm{R}$ was 0.973 which shows the correlation coefficient between the market price and the EPS, P/E ratio, DPR. Since, the coefficient was 0.973 it depicts that there is a strong positive relationship between EPS, P/E, DPR and the market share price thus in the top gainer commercial banks as the EPS, P/E, DPR increases the market share price also increases and vice versa. In all the regression models in this chapter the standard error of estimates shows the average deviation from the linear of best among the variables under investigation.

Table 4.4: Test of ANOVA for top gainer commercial banks in Nepal

\begin{tabular}{lccccc}
\hline \multicolumn{5}{c}{ ANOVA } \\
\hline & Sum of Squares & df & Mean Square & F & Sig. \\
\hline Regression & 18825349.578 & 3 & 6275116.526 & 124.764 & 0.000 \\
Residual & 1056210.422 & 21 & 50295.734 & & \\
Total & 19881560.000 & 24 & & & \\
\hline
\end{tabular}

The $\mathrm{F}$ statistics is used as a test for the model goodness of fit, $\mathrm{F}=124.764$, $\mathrm{p}$ value $<0.05$ shows that there is a significant relationship between market price per share and the EPS, $\mathrm{P} / \mathrm{E}, \mathrm{DPR}$ in top gainer commercial banks. The regression sum of squares shows the sum of the squared deviation from the line of best fit to the respective observed variables, residual sum of squares shows the sum of squared deviations which cannot be explained by the model while the total sum of squares shows the sum of squared deviations which has been explained and unexplained by the regression model. The degrees of freedom (df) 
for the regression model was 3 corresponding with the number of independent variables (EPS, P/E, DPR) and 24 in overall corresponding with the response rate minus 3 while the degrees of freedom for residual were 21 (24-3). The F statistics is the ratio between regression mean sum of square and residual sum of squares.

Table 4.5: Regression coefficients of top gainer commercial banks in Nepal

\begin{tabular}{lcccccccc}
\hline & \multicolumn{7}{c}{ Coefficients } \\
& $\begin{array}{c}\text { Unstandardized } \\
\text { Coefficients }\end{array}$ & \multicolumn{3}{c}{$\begin{array}{c}\text { Standardized } \\
\text { Coefficients }\end{array}$} & T & Sig. & $\begin{array}{c}\text { Collinearity } \\
\text { Statistics }\end{array}$ \\
& B & Std. Error & Beta & & & Tolerance & VIF \\
\hline (Cons) & -1049.916 & 212.85 & & -4.93 & .00 & & \\
EPS & 21.939 & 2.77 & 0.481 & 7.91 & .00 & 0.684 & 1.46 \\
PE & 55.548 & 3.56 & 0.968 & 15.57 & .00 & 0.655 & 1.52 \\
DPR & -262.113 & 118.82 & -0.160 & -2.20 & .03 & 0.479 & 2.08 \\
\hline
\end{tabular}

The above table 4.5, regression coefficients were used to show the relationship between EPS, P/E, DPR and the share price in top gainer commercial banks. The study findings revealed that there was a positive significant relationship between the EPS, P/E and the share price in top gainer commercial bank whereas DPR has negative relationship with MPS. Since, the $t$ ratio was $7.91,15.57,-2.20$ respectively and the $p$ value was less than 0.05 . The Collinearity Statistics shows the exact and linear relation between dependent and independent variable with Tolerance $<1$ and VIF (Variance Inflation Factor) $<10$.

\section{The regression model/line is given by following equation:}

$\mathrm{Y}=-1049.916+0.481 \mathrm{X} 1+0.968 \mathrm{X} 2-0.160 \mathrm{X} 3+\varepsilon$

Where,

$\mathrm{Y}=$ Market price of share (MPS)

$\mathrm{X} 1=$ Earning per share (EPS)

$\mathrm{X} 2=$ Price - Earning Ratio (P/E Ratio)

X3= Dividend Payout Ratio (DPR)

$\mathcal{E}=$ a random error

This implies that a unit changes in the EPS, P/E and DPR leads to $0.481,0.968$ and -0.160 changes in share price in the top gainer commercial banks in Nepal. 
Table 4.6: Correlation analysis of factor affecting share price of top loser commercial banks in Nepal

\section{Correlations}

\begin{tabular}{lcccc}
\hline & EPS & P/E & DPR & MPS \\
\hline EPS & 1 & & & \\
P/E & -0.208 & 1 & & \\
DPR & 0.308 & 0.204 & 1 & 1 \\
MPS & 0.245 & 0.195 & $0.492^{*}$ & 1 \\
\hline
\end{tabular}

*. Correlation is significant at the 0.05 level (2-tailed).

Table 4.6 explains the correlation between factors affecting market share price of top loser commercial banks in Nepal. The major focus is given to EPS, P/E, DPR, MPS. Here, we can observe DPR and MPS have highest influences in each other with 0.492 correlation score. Similarly, EPS and MPS have 0.245 correlation score resulting a significant influence over each other. Weak positive correlation can be traced between P/E and MPS with correlation value of 0.195 . EPS and DPR have weak positive correlation with value of 0.308 whereas EPS and P/E have weak negative relationship and P/E and DPR have weak positive relationship with each other with value of -0.208 and 0.204 respectively.

\section{Table 4.7: Regression Model Summary of top loser commercial banks in Nepal}

$$
\text { Model Summary }
$$

\begin{tabular}{cccc}
\hline $\mathrm{R}$ & $\mathrm{R}$ Square & Adjusted R Square & Std. Error of the Estimate \\
\hline 0.519 & 0.269 & 0.165 & 107.940 \\
\hline
\end{tabular}

Table 4.7 above shows the model summary for the regression analysis between the market share price and EPS, P/E ratio, DPR in top loser commercial banks. The R squared was 0.269 which shows the model explanatory power depicted that $26.9 \%$ of the changes in the share price in loser commercial banks be explained by the announcement of dividend while the remaining percentage can be explained by other factors excluded in the model. The adjusted $\mathrm{R}$ square was $16.5 \%$ which shows the model explanatory power with the exclusion of the constant variable in the regression model. In addition, the coefficient for $\mathrm{R}$ was 0.519 which shows the correlation coefficient between the market price and the announcement of dividend i.e. EPS, P/E, DPR. Since, the coefficient was 0.519 it depicts that there is a weak positive relationship between EPS, P/E, DPR and the market share 
Raj Kumar Baral and Ajay Pradhan: Impact of Dividend Policy on Share Price of Commercial Bank in Nepal

price. Thus, in the top loser commercial banks as the EPS, P/E, DPR increases the market share price also increases and vice versa. In all the regression models in this chapter the standard error of estimates shows the average deviation from the linear of best among the variables under investigation.

Table 4.8: Test of ANOVA for top loser commercial banks in Nepal

\begin{tabular}{lccccc}
\hline \multicolumn{6}{c}{ ANOVA } \\
\hline & Sum of Squares & df & Mean Square & F & Sig. \\
\hline Regression & 90042.395 & 3 & 30014.132 & 2.576 & 0.081 \\
Residual & 244670.645 & 21 & 11650.983 & & \\
Total & 334713.040 & 24 & & & \\
\hline
\end{tabular}

The $\mathrm{F}$ statistics is used as a test for the model goodness of fit, $\mathrm{F}=2.576$, $\mathrm{p}$ value $>0.05$ shows that there is no significant relationship between market price per share and the EPS, P/E, DPR in top loser commercial banks. The regression sum of squares shows the sum of the squared deviation from the line of best fit to the respective observed variables, residual sum of squares shows the sum of squared deviations which cannot be explained by the model while the total sum of squares shows the sum of squared deviations which has been explained and unexplained by the regression model. The degrees of freedom for the regression model was 3 corresponding with the number of independent variables (EPS, P/E, DPR) and 24 in overall corresponding with the response rate minus 3 while the degrees of freedom for residual were 21 (24-3). The F statistics is the ratio between regression mean sum of square and residual sum of squares.

Table 4.9: Regression Coefficient of top loser commercial banks in Nepal

\section{Coefficients}

\begin{tabular}{lccccccc}
\hline & $\begin{array}{c}\text { Unstandardized } \\
\text { Coefficients }\end{array}$ & & $\begin{array}{c}\text { Standardized } \\
\text { Coefficients }\end{array}$ & T & Sig. & $\begin{array}{c}\text { Collinearity } \\
\text { Statistics }\end{array}$ & \\
& B & Std. Error & Beta & & & Tolerance & VIF \\
\hline (Cons) & 184.489 & 48.753 & & 3.78 & .001 & & \\
EPS & 1.898 & 2.681 & 0.145 & 0.708 & .487 & 0.829 & 1.20 \\
& & & & & & & \\
\hline
\end{tabular}


118 The International Research Journal of Management Sceince

Vol.3 No. 1 December 2018/ISSN 2542-2510
$\mathrm{P} / \mathrm{E}$
0.672
0.961
0.139
$0.699 \quad 492$
0.877
1.14
DPR
79.727
38.958
0.419
$2.046 \quad .053$
0.830
1.21

The regression coefficients were used to show the nature of the relationship between EPS, $\mathrm{P} / \mathrm{E}, \mathrm{DPR}$ and the share price in top loser commercial banks. The study findings revealed that there was a positive significant relationship between the EPS, P/E ratio and DPR and the share price in top loser commercial banks since the t ratio was $0.708,0.699$ and 2.046 respectively and the $\mathrm{p}$ value was greater than 0.05 . The Collinearity Statistics shows the exact and linear relation between dependent and independent variable with Tolerance $<$ 1 and $\mathrm{VIF}<10$.

The regression model/line is given by following equation:

$\mathrm{Y}=184.489+0.145 \mathrm{X} 1+0.139 \mathrm{X} 2+0.419 \mathrm{X} 3+\varepsilon$

This implies that a unit changes in the EPS, P/E and DPR leads to $0.145,0.139$ and 0.419 respectively changes in share price in the top gainer commercial banks.

\section{Conclusion}

The main purpose of the study was to examine the relationship between dividend policy and the market share price of selected 10 commercial banks of Nepal and to what extent these factors affect the share price during the study period. The results of the study depict that there are several considerations made prior to issuing dividends to the shareholders. These consist of dividends paid in the previous years, the dividends to be paid to the preferred shareholders, what the rival banks pay, the net earnings during the period, the amount in the reserve fund and the investment prospects.

By using regression, correlation analysis and Wilcoxon Sign Rank Test, the study found that positive relationship between EPS, P/E, DPR and MPS on top loser commercial banks of Nepal whereas negative relationship with DPR in top gainer banks. Based upon the analysis and interpretation of the data, out of sampled top five gainers and top five losers commercial banks; among them except two banks showed that their market price is responsive to the dividend announcement. This means $80 \%$ of sample banks support that their market price of share changes due to the announcement of dividend. Thus, Nepalese commercial bank has significant impact on dividend in their market share price.

\section{Recommendation for Managerial Implication and Future Research}

It was necessary to conduct a study regarding the impact of dividend policy on the share price of commercial banks in Nepal. Thus, based on the findings of the study, investors and portfolio analysts are recommended to use the information regarding the factors they should consider for their investment decision and while predicting future dividends. 
When they want to select the dividend paying firms, they have to consider the factors before selecting investment options.

Board of directors and directors of financial department of banks are also advised to consider which factors have more determinant impact when they determine the dividend. The result of this study suggests investors, board of directors and head of finance department of Nepalese commercial banks to give consideration to dividend announcement, EPS, $\mathrm{P} / \mathrm{E}$ ratio, DPR before they invest and set the dividend policy. This will help to decide whether firms should keep retained earnings for future projects, for debt settlement, and/ or for dividend decisions which is an efficient, effective, and reasonable dividend payout decision.

A similar study should be done whereby the data collection relies on primary data that is, in-depth questionnaires and interview guide so as to complement this study. Due to the shortcomings of regression and correlation models, Wilcoxon Signed Rank Test; other models can be used to explain the various relationships between EPS, P/E, DPR and the value of the firms. Since, there are qualitative characteristics such as the political factors, legal factors. Similarly, quantitative factors like company size, age, goodwill, market to book value, CEO tenure, CEO duality among others which can influence the share price apart from the dividend, a study should be carried to determine their combined effect and their relationship with the share price.

\section{References}

Adhikari, K. K. (2063). “The Comparative Study of Dividend Policy and Practices Commercial Banks in Nepal” Kathmandu: Shanker Dev Campus.

Adres, C., Betzer, A., Bongard, I.V. D, Haesner, C. \& Theissen E (2009). Dividend announcement, market expectation and corporate governance. Available online on: http://www.fep.up.pt retrieved on 25/3/2015.

Alli K, Khan A, Ramirez G. (1993) "Determinants of dividend policy: a factorial analysis". The Finance Review, Vol 28: 523-47.

Bhandari, B. and T. Pokhrel (2012). Corporate Dividend policy: A Study of Commercial Banks of Nepal. Journal of Administrative and Management Review, 24 (2): pp. 24-44

Bhattari, B. H. (2052). “Dividend Decision \& Its Impact on Stock Valuation”. Kathmandu: Shanker Dev Campus. 
Bista, S. (2062). "Dividend Policy and Practices in Nepal: A Comparative Study of Listed Joint Venture Commercial Banks and Manufacturing Companies". Master Degree Thesis, Shanker Dev Campus, Kathmandu.

Faloye, B. A., \& Oluwole, F. O. (2014). "Dividend announcement on share prices in a bull and a bear market phase", Journal of Economics and International Finance, Vol 6(12), 272-283.

Gordon, M. J. (1963). “Optimal Investment and Financing Policy”. The Journal of Finance, Vol 18, 264-272.

Hussainey, K., Mgbame, C. O., \& Chijoke-Mgbame, A. M. (2011). "Dividend Policy and Share Price Volatility: UK Evidence". The Journal of Risk Finance, Vol 12 (1), 57 - 68.

Kowaleski, O., Stetsyuk I. and Talavera, O. (2007), "Corporate Governance and Dividend Policy in Poland”, Wharton Financial Institutions Centre Working Paper No. 07-09.

Lintner, J. (1956). “Distribution of Incomes of Corporations among Dividends, Retained Earnings and Taxes". The American Economic Review, Vol 46(2), 97-113.

Miller, M.H. \& Modigliani, F. (1961). "Dividend policy, growth, and the valuation of shares”. The Journal of Business, Vol 34(4), 411-433. Available at: http://about.jstor. org/terms

Appendix I

Reaction of share price before and after announcement of dividend: Result of Wilcoxon Signed Rank Test

\begin{tabular}{lccccccc|cc}
\hline Bank & $\sum(\mathrm{w}+)$ & $\sum(\mathrm{w}-)$ & $\mu$ & $\Sigma$ & $\mathrm{T}(\mathrm{E})$ & $\mathrm{Z}$ value & $\mathrm{Z} \mid$ value & $\mathrm{Z} \alpha(0.05)$ \\
\hline NABIL & 325 & 0 & 7.5 & 3.71 & 0 & -2.021563342 & 2.02156 & 1.645 \\
NIB & 314 & -11 & 7.5 & 3.71 & 11 & 0.943396226 & 0.943396 & 1.645 \\
SCB & 325 & 0 & 7.5 & 3.71 & 0 & -2.021563342 & 2.02156 & 1.645 \\
EBL & 325 & 0 & 7.5 & 3.71 & 0 & -2.021563342 & 2.02156 & 1.645 \\
ADBL & 325 & 0 & 7.5 & 3.71 & 0 & -2.021563342 & 2.02156 & 1.645 \\
KBL & 315 & -10 & 7.5 & 3.71 & 10 & 0.673854447 & 0.673854 & 1.645 \\
CCBL & 277 & -33 & 7.5 & 3.71 & 33 & 6.873315364 & 6.873315 & 1.645
\end{tabular}


Raj Kumar Baral and Ajay Pradhan: Impact of Dividend Policy on Share Price of Commercial Bank in Nepal

$\begin{array}{lcccccccc}\text { JBNL } & 225.5 & -99.5 & 7.5 & 3.71 & 99.5 & 24.79784367 & 24.79784 & 1.645 \\ \text { MEGA } & 325 & 0 & 7.5 & 3.71 & 0 & -2.021563342 & 2.02156 & 1.645 \\ \text { CBL } & 219 & -106 & 7.5 & 3.71 & 106 & 26.54986523 & 26.54987 & 1.645\end{array}$

Reaction of share price: before and after announcement of dividend of NIB

\begin{tabular}{|c|c|c|c|c|c|c|}
\hline \multicolumn{7}{|c|}{ Nepal Investment Bank Ltd. } \\
\hline Year & $\begin{array}{l}\text { MPS before an- } \\
\text { nouncement of } \\
\text { dividend } \\
\text { (X) }\end{array}$ & $\begin{array}{l}\text { MPS after an- } \\
\text { nouncement of } \\
\text { dividend } \\
\text { (Y) }\end{array}$ & $\mathrm{D}=(\mathrm{X}-\mathrm{Y})$ & Rank & $\mathbf{W}+$ & W- \\
\hline \multirow[t]{5}{*}{$2012 / 13$} & 951 & 880 & 71 & 3 & 3 & \\
\hline & 950 & 897 & 53 & 2 & 2 & \\
\hline & 920 & 971 & -51 & 1 & & -1 \\
\hline & 933 & 1067 & -134 & 6 & & -6 \\
\hline & 938 & 1050 & -112 & 4 & & -4 \\
\hline \multirow[t]{5}{*}{$2013 / 14$} & 920 & 750 & 170 & 14 & 14 & \\
\hline & 925 & 760 & 165 & 13 & 13 & \\
\hline & 940 & 768 & 172 & 15 & 15 & \\
\hline & 930 & 783 & 147 & 12 & 12 & \\
\hline & 895 & 765 & 130 & 5 & 5 & \\
\hline \multirow[t]{5}{*}{$2014 / 15$} & 1002 & 733 & 269 & 21 & 21 & \\
\hline & 998 & 720 & 278 & 23 & 23 & \\
\hline & 997 & 727 & 270 & 22 & 22 & \\
\hline & 1032 & 718 & 314 & 24 & 24 & \\
\hline & 1033 & 705 & 328 & 25 & 25 & \\
\hline
\end{tabular}


122 The International Research Journal of Management Sceince

Vol.3 No. 1 December 2018/ISSN 2542-2510

\begin{tabular}{|c|c|c|c|c|c|c|}
\hline \multirow[t]{5}{*}{ 2015/16 } & 1090 & 883 & 207 & 17 & 17 & \\
\hline & 1070 & 871 & 199 & 16 & 16 & \\
\hline & 1070 & 852 & 218 & 18 & 18 & \\
\hline & 1085 & 840 & 245 & 20 & 20 & \\
\hline & 1068 & 828 & 240 & 19 & 19 & \\
\hline \multirow[t]{6}{*}{ 2016/17 } & 764 & 629 & 135 & 7 & 7 & \\
\hline & 764 & 623 & 141 & 10 & 10 & \\
\hline & 757 & 620 & 137 & 8 & 8 & \\
\hline & 760 & 620 & 140 & 9 & 9 & \\
\hline & 768 & 625 & 143 & 11 & 11 & \\
\hline & & & & & $\sum(W+)=314$ & $\sum(W-)=-11$ \\
\hline
\end{tabular}

